\title{
Study of degumming process and evaluation of oxidative stability of methyl and ethyl biodiesel of Jatropha curcas L. oil from three different Brazilian states
}

\author{
Francisca Diana da Silva Araújo ${ }^{a}$, Iranildo C. Araújo ${ }^{a}$, Isabella Cristhina G. Costa ${ }^{a}$, \\ Carla Verônica Rodarte de Moura a, Mariana H. Chaves ${ }^{a,}{ }^{*}$, Eugênio Celso E. Araújo b \\ a Departamento de Química - CCN, Universidade Federal do Piauí, 64049-550 Teresina, PI, Brazil \\ ${ }^{\mathrm{b}}$ Empresa Brasileira de Pesquisas Agropecuária - Embrapa Meio-Norte, 64049-550 Teresina, PI, Brazil
}

\section{A R T I C L E I N F O}

\section{Article history:}

Received 16 September 2013

Accepted 1 June 2014

Available online

\section{Keywords:}

Jatropha curcas

Degumming

Biodiesel

Transesterification reaction

Oxidation stability

Thermogravimetric analysis

\begin{abstract}
A B S T R A C T
This work describes the production of biodiesel from Jatropha curcas oil. The kernel samples provided by Embrapa-PI, were first crushed in a blender and then subjected to extraction with hexane. The oil yield was between $54.71 \pm 0.47$ and $64.16 \pm 2.88 \%$. The J. curcas oil was then submitted to two different kinds of degumming, first with water and second with $\mathrm{H}_{3} \mathrm{PO}_{4}$ to evaluate the influence of these processes in the yield of the transesterification reaction. Methyl and ethyl biodiesel prepared from the degummed oil with $\mathrm{H}_{3} \mathrm{PO}_{4}$ had higher conversions than those prepared with the degummed with water. Therefore, among the processes of degumming studied, $\mathrm{H}_{3} \mathrm{PO}_{4}$ was more suitable for the treatment of $J$. curcas oil. The study shows the results about oxidation stability were good, because the biodiesels methyl and ethyl biodiesel have induction period at $13.51 \mathrm{~h}$ and $13.03 \mathrm{~h}$ without antioxidant addition when submitted a Rancimat text. Such biodiesels had their physicochemical parameters defined under the specifications of ANP Resolutions n' 14/2012 (ANP- National Agency of Petroleum, Natural Gas and Biofuels from Brazil). The results showed that $J$. curcas cultivation in Brazil is an adequate source for biodiesel production, considering the technical standards available.
\end{abstract}

() 2014 Elsevier Ltd. All rights reserved.

\section{Introduction}

Global warming, a spurt in population growth and an increase in demand for transport fuels in developing economies, all coupled together with limited reserves of fossil fuels, are realities that have convinced many countries of the need to develop alternative and renewable energy sources such as biofuels [1]. Currently, most biofuels are obtained from either carbohydrate-based feedstock (sugar, starch, cellulose) or oil-based feedstock [2]. Oil-based feedstock or biodiesel can be produced from vegetable oils of agricultural plants such as rapeseed, sunflower, soybean, oil palm and groundnut [2]. As a feedstock, more than $80 \%$ of Brazilian biodiesel production is derived from soybean oil [2]. However, in accordance to Johnson et al., the use of edible oils in developing countries for biofuel purposes could lead to shortages of edible oils or an escalation of their prices [2]. Besides, the cost of biodiesel is

\footnotetext{
* Corresponding author. Tel.: +55 863215 5841; fax: +55 8632371812 .

E-mail address: mariana@ufpi.edu.br (M.H. Chaves).
}

not competitive to petroleum diesel without subsidies or tax incentives as the cost of raw materials is high. The cost of crop oil accounts for a large percent of direct biodiesel production cost which includes capital cost and returns [3]. Therefore, it is necessary to find new feedstock suitable for biodiesel production, which would not drain the edible vegetable oil supply and that would be capable of growing in marginal lands with minimum agricultural inputs. Besides, from the industrial point of view, using unrefined oils is very important since the refining of oil is a costly process [4]. However, the use of crude oil, without at least going through the process of degumming and neutralization, can cause problems such as emulsification in the transesterification process. By degumming, the impurities like protein, phosphatides, colorants, etc, are removed [5].

Non-edibles oils such as jatropha oil, castor oil and others are considered to be renewable and sustainable solutions [6].

Jatropha curcas L. or physic nut, belonging to the Euphorbiaceae family, is seen as one of the most appropriate renewable alternative sources of biodiesel in terms of availability and cost $[7,8]$. It is a perennial plant that is easily cultivated, requires much sunshine, is 
strongly resistance to drought and grows under a wide range of regional rainfall from 200 to $1500 \mathrm{~mm}$ per year [8], and it is a hardy plant amenable to cultivation on marginal land [9]. This condition provides an alternative oil source without directly competing with food production [10]. This type of condition is found in northeastern Brazil, where there is a large arid area that is in need of development. Due of the potential to transform J. curcas oil in biodiesel, their cultivation area, mainly in India, China, Mexico and Brazil are growing [11]. The new demand for development to improve of cultivars, in recent years, leading the cultivation and domestication of $J$. curcas [11].

The productivity of this species varies by planting region, cultivation method and soil fertility [12]. The production of J. curcas reached levels around $8000 \mathrm{~kg}$ of seed per hectare per year [13]. The maximum productivity of the plant occurs in five years and it can survive for more than 50 years. The fruit's ripening occurs in 30-45 days, observing the changes in color from green to yellow, to brown and finally, to black $[14,15]$. Jatropha is considered unsuitable for ingestion in certain cases because the oral intake of its leaves and seeds can cause hypercatharsis or diarrhea; moreover, it contains the toxin curcin (a protein with a molecular weight of $28.2 \mathrm{kDa}$ and 251 amino acids) as well as phorbol esters which are known for being tumor-promoters in cell proliferation, activation of blood platelets, lymphocyte mitogenesis, inflammation (erythema of the skin), prostaglandin production and stimulation of degranulation in neutrophils $[16,17]$. Curcin becomes nontoxic on denaturation by heating; however, phorbol esters persist in oil fractions [18].

Jatropha curcas can still be considered as a semi-wild, undomesticated plant, showing considerable performance variability, and the profit margin realized from this crop is still very small compared in its cultivation [11]. Then a study about variety of oil in different species is very important.

The seed cake has been used as a natural fertilizer since it is rich in NPK. The cake contains about $6 \%$ nitrogen, $3 \%$ phosphorus, $1 \%$ potassium, and traces of calcium and magnesium. After detoxification, this product can be used as animal feed [13].

J. curcas nuts contain $40.0-60.0 \%$ of oil, $4.0-4.7 \%$ of ash, $3.7-10.1 \%$ of fiber, $17.8-28.9 \%$ of protein and $4.4-5.5 \%$ of moisture. The composition of seed oil includes capric acids $(0.0-0.1 \%)$, myristic (0.0-1.4\%), palmitic (13.0-19.5\%), palmitoleic (0.8-1.4\%), stearic $(6.8-9.7 \%)$, oleic $(34.3-53.0 \%)$, linoleic $(20.0-43.2 \%)$, linolenic $(0.0-3.0 \%)$, arachidic $(0.0-0.4 \%)$ and behenic $(0.0-0.2 \%)$ $[14,19-22]$. Table 1 shows the composition of the oil varieties from different regions of the world. It is observed that in some areas the major constituent of oil is oleic acid, while in others it is linoleic acid.

J. curcas as a substitute for diesel fuel will be very import, since the oil has calorific contents, which were $4980.3 \mathrm{cal} \mathrm{g}^{-1}$ for the seed, $9036.1 \mathrm{cal} \mathrm{g}^{-1}$ for the fraction of oil, and $9704.4 \mathrm{cal} \mathrm{g}^{-1}$ for the

Table 1

Fatty acids composition of $J$. curcas (\% p/p of methyl ester).

\begin{tabular}{lccllll}
\hline Fat acid & $\begin{array}{l}\text { Caboverde } \\
{[14]}\end{array}$ & $\begin{array}{l}\text { Nicaragua } \\
{[14]}\end{array}$ & $\begin{array}{l}\text { Benin } \\
{[21]}\end{array}$ & $\begin{array}{l}\text { Mexico } \\
{[21]}\end{array}$ & $\begin{array}{l}\text { Togo } \\
{[21]}\end{array}$ & $\begin{array}{l}\text { Brazil } \\
{[21]}\end{array}$ \\
\hline C10:0 & 0.1 & 0.1 & - & - & - & - \\
C14:0 & 0.1 & 0.1 & - & - & - & - \\
C16:0 & 15.1 & 13.6 & 14.6 & 15.2 & 15.0 & 13.1 \\
C16:1 & 0.9 & 0.8 & 0.8 & - & - & - \\
C18:0 & 7.1 & 7.4 & 7.4 & 9.1 & 6.0 & 6.6 \\
C18:1 & 44.7 & 34.3 & 47.5 & 37.5 & 44.0 & 32.8 \\
C18:2 & 31.4 & 43.2 & 28.7 & 38.0 & 35.7 & 46.9 \\
C18:3 & 0.2 & 0.2 & 1.0 & - & - & - \\
C20:0 & 0.2 & 0.3 & - & - & - & - \\
C22:0 & 0.2 & - & - & - & - & - \\
\hline
\end{tabular}

fraction of hydrocarbons [23]. Many researchers have studied the potential of oil J. curcas for use in biodiesel production [24-26].

The literature shows the non-refined $J$. curcas oils revealed a high content in free fatty acids (about 15-20\%), hence this can leads to soap formation and lower yield of biodiesel if the catalyst is basic [27]. Crude oil also contains many gums, such as phospholipids, which can deactivate the catalyst during biodiesel production and reduce drastically the conversion of methyl esters [28].

The aim of this study was to extract, characterize the oil from the fruit seeds of $J$. curcas, grown in northeastern Brazil, as well as do two texts degumming of oil procedures, and subsequent application to obtain biodiesel, and study the oxidative stability of jatropha biodiesel, using Rancimat technique.

\section{Materials and methods}

\subsection{Instruments}

The physicochemical characterizations were performed using automatic densimeter Anton Paar DMA 4500, viscometer Quimis ${ }^{\mathbb{Q}}$, Metrohm Rancimat 743. Benchmark unit 2000, Koehler Instrument Company, Inc. (determination of water and sediment); apparatus Pensky Martens Closed Cup APM-7 (measured flash point); equipment Petrotest $^{\circledR}$ (copper corrosivity); Tanaka Scientific Limited-AFP 102 (filter plugging point of the cold). The percentages of total and free glycerin, mono-, di- and Triacylglycerol were obtained in a gas chromatograph with a flame ionization detector (GC-FID), Varian 3800 and the methanol content by GC-FID coupled with static headspace, Varian 3900. To determine the composition of oil, a Shimadzu gas chromatograph model GC17A with mass detector (GC-MS) QP5000 was used. NMR spectrometer Varian Inova $500(500 \mathrm{MHz})$ and TGA-2050 balance TA Instruments were used to obtain the NMR and TGA spectra, respectively. Some of the parameters were performed in triplicate, and presented both the mean and standard deviation measures.

\subsection{Collection of seeds}

Mature and sun-dried seeds of Jatropha curcas L. were collected from trees in different regions of Brazil and donated by EMBRAPA Brazilian Company of Agriculture and Livestock. The samples came from of three different cities (Teresina, Crateús and Janaúba). Teresina is located at Piauí State (northeast of Brazil), Crateús is located at Ceará State (northeast of Brazil) and Janaúba is located at Minas Gerais State (southeast of Brazil). All of these cities are located in very dry and hot climates.

\subsection{Determination of oil composition fatty acid}

Fatty acid methyl esters (FAME) were prepared following the methodology described by IUPAC with some modifications [29-31]. $100 \mathrm{mg}$ of jatropha oil was accurately weighed into a $20 \mathrm{~mL}$ centrifuge tube and a methanolic $\mathrm{KOH}$ solution $\left(2 \mathrm{~mol} \mathrm{~L}^{-1}\right)$ was added $(0.2 \mathrm{~mL})$. The tube was sealed and mixed vigorously for $20 \mathrm{~min}$ in a vortex shaker. Saturated $\mathrm{NaCl}$ solution $(2.0 \mathrm{~mL})$ was added and the organic phase was separated. An aliquot $(1.0-2.0 \mu \mathrm{L})$ of the hexane solution was submitted to GC-MS analysis, under the following conditions: Capillary column: 5\% phenylmethylpolysiloxane DB-5 (30 m $\times 0.25 \mathrm{~mm}, 0.25 \mu \mathrm{m}$ film thickness); carrier gas: helium; flow $0.6 \mathrm{~mL} / \mathrm{min}$; acquisition time from $42.5 \mathrm{~min}$ and solvent cut in $4 \mathrm{~min}$; mass range from 40 to 400 , electron energy of $70 \mathrm{eV}$; multiplier voltage of $1.3 \mathrm{kV}$; analyzer quadrupole; injector temperature: $230{ }^{\circ} \mathrm{C}$; interface temperature: $250{ }^{\circ} \mathrm{C}$; column temperature: $150{ }^{\circ} \mathrm{C}(2 \mathrm{~min}) ; 150-230^{\circ} \mathrm{C}$ at $5^{\circ} \mathrm{C} /$ min; $230{ }^{\circ} \mathrm{C}(7 \mathrm{~min}) ; 230-260{ }^{\circ} \mathrm{C}$ at $4{ }^{\circ} \mathrm{C} / \mathrm{min} ; 260{ }^{\circ} \mathrm{C}(10 \mathrm{~min})$. 
Individual components were identified by computer search (Wiley 229 library).

\subsection{Extraction of the oil for biodiesel synthesis}

The samples of $J$. curcas kernels provided by EMBRAPA from Teresina-Piauí, Crateús-Ceará and Janaúba-Minas Gerais, were crushed in a blender and submitted to extraction with hexane for $18 \mathrm{~h}$ in Soxhlet. At the end of extraction, the solvent was removed in rotary evaporator at $50{ }^{\circ} \mathrm{C}$. This procedure was performed several times until we obtained approximately $2 \mathrm{~L}$ of oil. The $J$. curcas oil was degummed with water or $\mathrm{H}_{3} \mathrm{PO}_{4}$ [32] in order to evaluate the process's influence on the conversion of triacylglycerol into methyl or ethyl esters.

\subsubsection{Degumming of oil with water}

In a beaker of $250 \mathrm{~mL}, 100 \mathrm{~g}$ of oil and $3 \mathrm{~mL}$ of heated water $\left(70{ }^{\circ} \mathrm{C}\right)$ were added. The mixture was stirred for $30 \mathrm{~min}$, and after, was left to decant. The precipitate was removed and the oil was filtered off in anhydrous sodium sulfate [32].

\subsubsection{Degumming of oil with $\mathrm{H}_{3} \mathrm{PO}_{4}$}

The crude oil $(1000 \mathrm{~mL})$ was pre-heated at $60{ }^{\circ} \mathrm{C}, 0.1 \%$ of phosphoric acid (based on the mass of oil used), some $\mathrm{NaOH}(8 \%)$ sufficient to neutralized $70-90 \%$ of added acid, and $2 \%$ of water. The mixture was heated and stirred until the formation of the gum. Subsequently, the mixture was cooled and the gum was separated from the solution by simple filtration. This procedure was repeated using 3\% water, to remove the remaining gums. The oil was filtered off with anhydrous sodium sulfate [32].

\subsection{Biodiesel synthesis}

The ethyl and methyl biodiesel were synthesized using J. curcas oil from Teresina-Piauí seeds. The transesterification reaction was performed using rates of 100:20:1 (oil: methanol: $\mathrm{NaOH}$ ) and 100:40:1 (oil: ethanol: $\mathrm{NaOH}$ ) [33] under constant stirring for a period of 60 or $120 \mathrm{~min}$ for methyl and ethyl esters, respectively, at room temperature [34,35]. At the end of the reaction, the mixture was transferred to a decanting funnel and the esters were separated from the glycerin, washed with water and heated to $100{ }^{\circ} \mathrm{C}$. The biodiesel was analyzed by TLC with silica gel using as eluent hexane-EtOAc (95:5). The spots on the TLC plates were revealed with iodine steam. The reaction yield was calculated by the formula:

Yield $(\%)=($ mass of biodiesel/oil mass $) \times 100$.

The rate of conversion of triglyceride oil into biodiesel was determined by ${ }^{1} \mathrm{H}$ NMR analysis in $\mathrm{CDCl}_{3}$ and using the following expression [36]:

$\mathrm{C}=\frac{2 \mathrm{ACH}_{3}}{3 \mathrm{ACH}_{2}} \times 100$

where:

$C=\%$ conversion

$\mathrm{ACH}_{3}=$ integration area of the signal at $\delta 3.7$ from hydrogen methoxylic

$\mathrm{ACH}_{2}=$ integration area of the signal at $\delta 2.3$ from methylene hydrogen $\alpha$-carbonyl esters and triacylglycerol.

The conversion of triacylglycerol into ethyl esters was effected from the equation [37]
$C=\frac{2 \mathrm{ACH}_{2}}{3 \mathrm{~A}^{\prime} \mathrm{CH}_{2}} \times 100$

where:

$\mathrm{C}=\%$ conversion

$\mathrm{ACH}_{2}=$ integration area of the signal at $\delta 3.7$ from ethoxylates

$\mathrm{A}^{\prime} \mathrm{CH}_{2}=$ integration area of the signal at $\delta 2.3$ from metylene hydrogen $\alpha$-carbonyl esters and triacylglycerol.

\subsection{Physicochemical analysis and thermogravimetric oil and biodiesel}

The physicochemical properties of biodiesel were done according to the rules of the American Society of Testing and Materials (ASTM) and Comité Européen of Normalisation (CEN) listed in ANP Resolution 14/2012 [38] of the National Agency of Petroleum, Natural Gas and Biofuels from Brazil. The acidity index of oil and biodiesel, and the saponification index of the oil were carried out in accordance with the standards of the Adolfo Lutz Institute. TG curves of the oils of $J$. curcas crude, degummed with water and degummed with acid, as well as biodiesel were obtained in a temperature range $30-600{ }^{\circ} \mathrm{C}$ with a heating rate of $10{ }^{\circ} \mathrm{C} / \mathrm{min}$ in nitrogen atmosphere with a flow rate of $50 \mathrm{~mL} / \mathrm{min}$ using an aluminum pot with a hole in the lid of about $0.5 \mathrm{~mm}$ in diameter. The weight loss of the sample was determined as the difference between the initial and final weight loss. The boiling point was taken as the point of intersection of the tangent of the slope of mass loss with the initial baseline (temperature "onset"). The software of the equipment was used to draw the tangent lines and compute the boiling temperature [39-41].

\subsection{Tests for oxidation stability}

The oxidation stability was measured according to EN 14112 , where $3 \mathrm{~g}$ of samples were analyzed under heating at $110{ }^{\circ} \mathrm{C}$ and constant air flow $(10 \mathrm{~L} / \mathrm{h})$. In the Rancimat, the flow of air passes through the sample, and then bubbles into a flask containing deionized or distilled water, dragging the volatile carboxylic acids (breakdown products), which solubilize and increase the conductivity of the water. The response is a curve of conductivity versus time in which two tangents intersect at a point, corresponding in time scale, the induction period or oxidation stability [42].

\section{Results and discussion}

\subsection{Characterization of oil of J. curcas}

\subsubsection{Chemical composition and yield of oil}

The seeds from Janaúba-Minas Gerais had higher yield in oil, $64.16 \pm 2.88 \%$, while the sample from Teresina-Piauí exhibited an intermediate value, $60.69 \pm 0.84 \%$, and the seeds coming from Crateus-Ceará were those that obtained a lower yield, $54.71 \pm 0.47 \%$. The sample results were compared by analysis of variance (ANOVA) and showed that the values are significantly different at a significance level of $5 \%$. These results indicate that the quantity of the oil yield from $J$. curcas seeds can vary depending on the region of cultivation, and may be influenced by the conditions, culture or even age [18]. Table 2 lists the compositions of the J. curcas oils from the Janaúba-Minas Gerais, Teresina-Piauí, Crateús-Ceará, and Caboverde-Africa variety, for comparative purposes, in addition to the compositions for soybean oil $[14,21]$. 
All the samples from $J$. curcas oil showed a percentage of oleic acid (18: 1) greater than linoleic acid (18:2), thus resembling the range of Caboverde variety. With regards to the content of unsaturated acids, we observed lower values compared with the percentage found in the literature for soybean oil. The increase in unsaturated acids provides a decrease in oxidation stability of oil and consequently of biodiesel [43].

\subsubsection{Physicochemical characterization of oil}

The crude oil extracted from the seeds supplied by TeresinaPiauí, and the oils subjected to degumming with water and $\mathrm{H}_{3} \mathrm{PO}_{4}$ showed the physicochemical properties listed in Table 3.

The ANOVA test was applied in the values found to acidity index and results were significantly different, with a significance level of $5 \%$. When the crude oil was degummed with water, a decrease in content of free fatty acids present was verified. A reduction of approximately $50 \%$ in the acidity index was observed when the degumming was done with phosphoric acid. All samples showed an acidity index above the limit established for refined oils, whose value is less than $0.6 \mathrm{mg} \mathrm{KOH} / \mathrm{g}$ oil [30].

The rate of the saponification index varies with the nature of fatty acids that comprise the triacylglycerol. The lower the average molecular weight of these compounds, the higher the value of this parameter [32]. There was no significant difference between the values of the saponification index between the three samples $[14,20,21]$.

The density values obtained for all samples found in the range observed in the literature $[21,34,44]$ from 0.8950 to $0.9186 \mathrm{~kg} / \mathrm{m}^{3}$.

The induction periods obtained for the oils of $J$. curcas crude, degummed with both water and with $\mathrm{H}_{3} \mathrm{PO}_{4}$ were 7.92, 7.83 and 7:09 h, respectively (Table 3). A small decrease in the induction period of the crude oil was observed with application of the processes of degumming. However, the analysis of variance indicated no significant difference between these values, showing that the degumming does not affect the oxidative stability of oil.

\subsubsection{Thermogravimetric analysis}

TG/DTG curves of $J$. curcas crude oil from Teresina-Piauí subjected to water and $\mathrm{H}_{3} \mathrm{PO}_{4}$ degumming showed the thermal events listed in Table 4. Two thermal events were observed in the oils and can be attributed to the volatilization of triacylglycerols, the second event can be attributed to the volatilization of higher molecular weight triacylglycerols [41].

It was found that as crude oil goes through water degummed and acid-degummed processes, there is a slight decrease in the percentage of the total mass loss, suggesting that part of the phospholipids is actually withdrawn. Moreover, an increase in the $T_{\text {onset }}$ of the first event in the degummed oil was observed, especially in the latter case, suggesting that the removal of phospholipids may contribute to the increase of thermal stability of the oil.

Table 2

Composition of FAME to J. curcas oil (\% p/p).

\begin{tabular}{lllllc}
\hline Fatty acid & Teresina & Crateús & Janaúba & $\begin{array}{l}\text { Caboverde } \\
\text { variety [14] }\end{array}$ & $\begin{array}{l}\text { Soybean } \\
\text { oil [21] }\end{array}$ \\
\hline $16: 0$ & $14.69 \pm 1.33$ & $11.53 \pm 0.77$ & $11.35 \pm 0.32$ & 15.10 & 11.00 \\
$16: 1$ & $0.39 \pm 0.09$ & - & $0.34 \pm 0.19$ & 0.90 & - \\
$18: 0$ & $7.04 \pm 1.94$ & $7.09 \pm 0.81$ & $4.58 \pm 3.24$ & 7.10 & 4.00 \\
$18: 1$ & $42.30 \pm 2.42$ & $41.77 \pm 4.65$ & $42.64 \pm 8.49$ & 44.70 & 22.00 \\
$18: 2$ & $35.48 \pm 2.90$ & $39.60 \pm 4.97$ & $39.34 \pm 8.59$ & 31.40 & 54.30 \\
$18: 3$ & - & - & - & 0.20 & 7.50 \\
$20: 0$ & $0.09 \pm 0.04$ & - & $0.08 \pm 0.03$ & 0.20 & - \\
$\sum$ UFA (\%) & 78.17 & 81.15 & 82.21 & 77.00 & 83.80 \\
$\sum$ SFA (\%) & 21.82 & 18.62 & 16.01 & 22.40 & 15.00 \\
\hline
\end{tabular}

UFA: unsaturated fatty acids. SFA: saturated fatty acids.
Table 3

Physicochemical property of the $J$. curcas oils from Teresina-Piauí, crude oil (CO), degummed with water (DW) and degummed with $\mathrm{H}_{3} \mathrm{PO}_{4}$ (DPA).

\begin{tabular}{llll}
\hline Property & $\mathrm{CO}$ & $\mathrm{DW}$ & $\mathrm{DPA}$ \\
\hline $\begin{array}{l}\text { Acidity index } \\
\quad(\mathrm{mg} \mathrm{KOH} / \mathrm{g} \text { of oil) }\end{array}$ & $6.20 \pm 0.01$ & $5.00 \pm 0.00$ & $3.60 \pm 0.01$ \\
$\begin{array}{l}\text { Saponification index } \\
(\mathrm{mg} \mathrm{KOH} / \mathrm{g} \text { of oil) }\end{array}$ & $185.75 \pm 0.69$ & $186.99 \pm 0.45$ & $186.77 \pm 0.86$ \\
$\begin{array}{l}\text { Density, } 20^{\circ} \mathrm{C}\left(\mathrm{g} / \mathrm{cm}^{3}\right) \\
\text { Oxidation stability }\end{array}$ & $0.911 \pm 0.000$ & $0.914 \pm 0.000$ & $0.915 \pm 0.000$ \\
$\quad 7.92$ & 7.83 & $7: 09$ \\
\hline at $110{ }^{\circ} \mathrm{C}(\mathrm{h})$ & & & \\
\hline
\end{tabular}

No water was detected in the oil after degumming with water or $\mathrm{H}_{3} \mathrm{PO}_{4}$ as can be seen in the TG curve shown in Fig. 1.

\subsection{Characterization of J. curcas biodiesel}

\subsubsection{TLC and ${ }^{1} H$ NMR analysis}

Thin-layer chromatography (TLC) analysis of biodiesels suggested the occurrence of the transesterification reaction to the oils, especially for ethyl biodiesel where the oil was degummed with water (EB-DW) and ethyl biodiesel where the oil was degummed with $\mathrm{H}_{3} \mathrm{PO}_{4}$ (EB-DPA). In methyl biodiesels (MB-DW and MB-DPA), it has been verified that there is a presence of spots with retention factor $\left(R_{f}\right)$ similar to that of triacylglycerol oil, showing that it even left part of the starting material.

The ${ }^{1} \mathrm{H}$ NMR spectrum of $J$. curcas oil presented nine major signals consistent with the structure of triacylglycerols, a triplet in $\delta 0.85(J=6.4 \mathrm{~Hz})$, attributed to terminal methyl hydrogens of the

Table 4

Thermal events of $J$. curcas crude oil from Teresina-Piauí, water degumming, and $\mathrm{H}_{3} \mathrm{PO}_{4}$ degumming oil.

\begin{tabular}{llll}
\hline Samples & $\begin{array}{l}\text { Temperature } \\
\text { range }\left({ }^{\circ} \mathrm{C}\right)\end{array}$ & $\begin{array}{l}\text { Weight } \\
\text { loss }(\%)\end{array}$ & $\begin{array}{l}\text { Onset } \\
\text { temperature }\left({ }^{\circ} \mathrm{C}\right)\end{array}$ \\
\hline Crude oil & $307.95-446.44$ & 89.45 & 330.93 \\
& $446.44-495.63$ & 9.05 & 469.23 \\
& & $\sum \mathbf{9 8 . 5 0}$ & \\
Water degumming oil & $288.27-447.95$ & 87.02 & 355.19 \\
& $447.95-494.12$ & 11.11 & 470.85 \\
& & $\sum \mathbf{9 8 . 1 3}$ & \\
$\mathrm{H}_{3} \mathrm{PO}_{4}$ degumming oil & $304.16-447.20$ & 87.75 & 408.15 \\
& $447.20-505.47$ & 10.23 & 469.81 \\
& & $\sum \mathbf{9 7 . 9 8}$ & \\
\hline
\end{tabular}

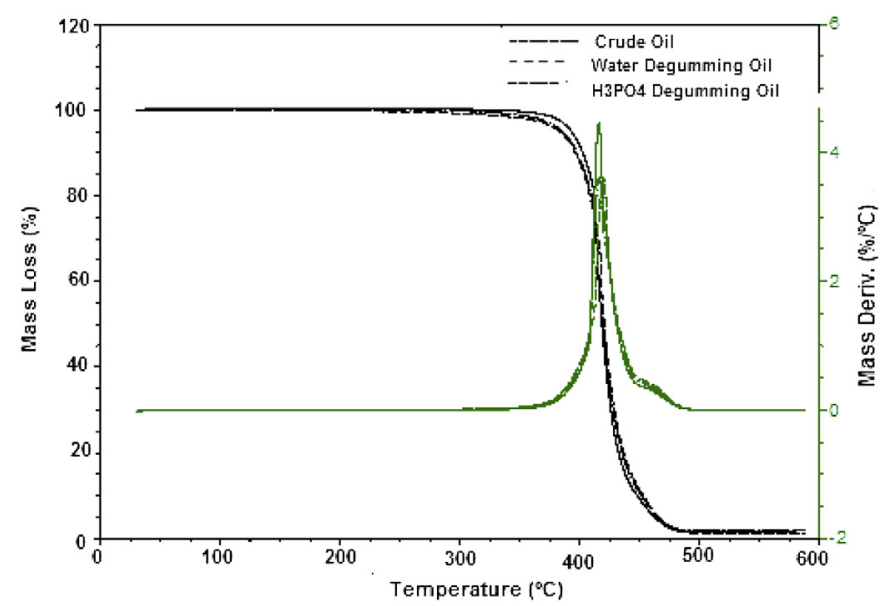

Fig. 1. TG and derived curve of crude, water degumming and $\mathrm{H}_{3} \mathrm{PO}_{4}$ degumming Jatropha curcas oil. 
hydrocarbon chain, a singlet at $\delta 1.23$ from chain methylene, a multiplet at $\delta 1.58$ from $\beta$-methylene carbonyl groups, a multiplet at $\delta 2.00$ from the allylic methylene hydrogens, two triplets at $\delta 2.28$ $(J=7.4 \mathrm{~Hz})$ and $2.75(J=7.0 \mathrm{~Hz}) \alpha$-methylene groups of carbonyl and bis-allylic, respectively, two signals at $\delta 4.11(\mathrm{dd}, J=6.0$ and $11.8 \mathrm{~Hz}$ ) and $\delta 4.27$ (dd, $J=4.2$ and $11.6 \mathrm{~Hz}$ ) from the hydrogens $\mathrm{CH}_{2} \mathrm{O}$ from glycerol portion, a multiplet between $\delta 5.90$ and 5.42 referent to the chain olefinic hydrogens and $\mathrm{CHO}$ of glycerol portion [45-47].

The NMR ${ }^{1} \mathrm{H}$ spectra of biodiesels from oils subjected to different processes of degumming were similar. The occurrence of the transesterification was confirmed by signals at $\delta 3.61(s)$ concerning the methoxyl and $\delta 4.06(q, J=7.0 \mathrm{~Hz})$, assigned to the oxymethylenic hydrogens to methyl and ethyl biodiesels, respectively $[45,46]$.

Through the ${ }^{1} \mathrm{H}$ NMR analysis, it was observed that the conversions in esters were relatively high for all J. curcas biodiesels, because there were no obvious signs placed between $\delta 4.10$ and 4.40 characteristic of triacylglycerols.

\subsubsection{Effect of degumming on the yield and conversion}

Degumming was done to decrease the acidity of the oils tested in this study, and to removal gums and other interferences that might reduce the yield of biodiesel.

The methyl and ethyl biodiesels had higher yields and conversions in esters, when prepared from oil degummed with $\mathrm{H}_{3} \mathrm{PO}_{4}$ (Fig. 2).

Phospholipids as well as some by-products formed during the process of obtaining biodiesel by transesterification alkaline, such as soaps, mono- and diacylglycerol, can act as surfactants [48], hindering the phase separation from the stabilization of emulsions, and helping to decrease yield and conversion rate. Whereas the degumming process with water does not produce the complete removal of phospholipids, since only a few of these have solubility in water [35], and probably a significant amount of these

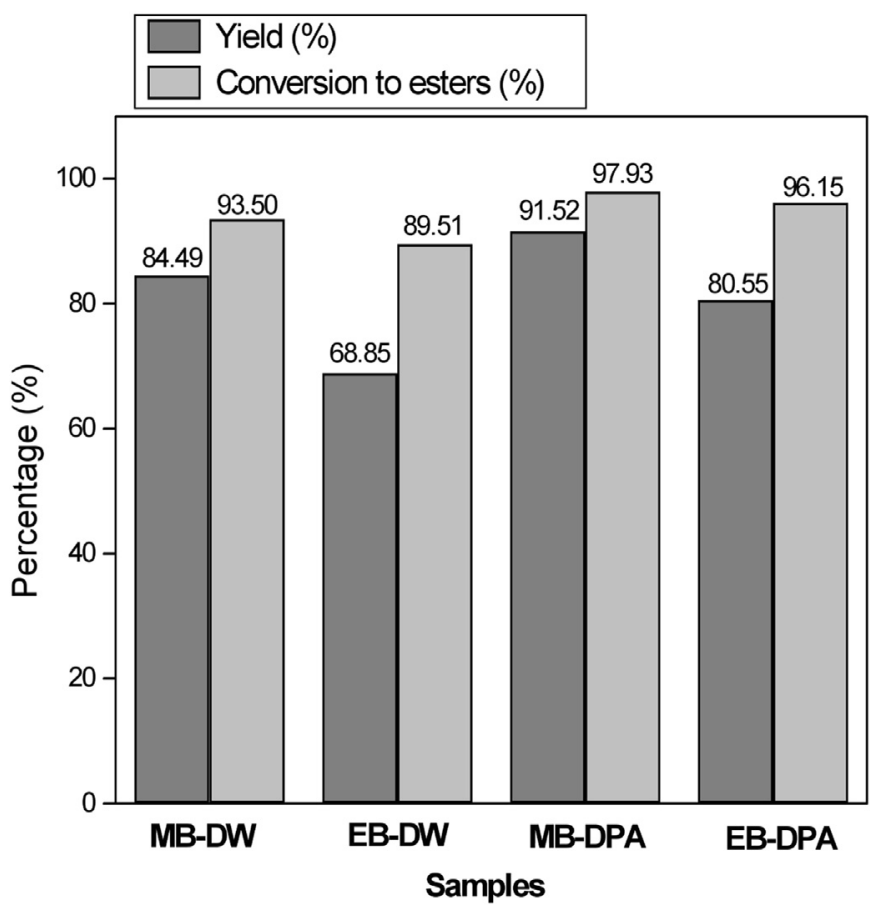

Fig. 2. Yield of biodiesel and percentage conversion of triacylglycerols to corresponding methyl and ethyl esters. MB: methyl biodiesel; EB: ethyl biodiesel; DW: degumming with water; DPA: degumming with $\mathrm{H}_{3} \mathrm{PO}_{4}$
Table 5

Thermal events of MBJC and EBJC.

\begin{tabular}{lcll}
\hline Samples & $\begin{array}{l}\text { Temperature } \\
\text { range }\left({ }^{\circ} \mathrm{C}\right)\end{array}$ & Weight loss $(\%)$ & $\begin{array}{l}\text { Onset } \\
\text { temperature }\left({ }^{\circ} \mathrm{C}\right)\end{array}$ \\
\hline MBJC & $79.40-246.65$ & 79.47 & 175.81 \\
& $246.65-301.14$ & 18.32 & 287.52 \\
EBJC & & $\sum \mathbf{9 7 . 7 9}$ & 186.17 \\
& $77.88-263.30$ & 80.10 & 319.19 \\
& $263.30-338.22$ & 18.75 & \\
\hline
\end{tabular}

substances remained present in the reaction medium, contributing to the reduction in income from transesterification of $J$. curcas oil.

In turn, in the degumming process with $\mathrm{H}_{3} \mathrm{PO}_{4}$, non-hydratable phospholipids are decomposed and transformed into insoluble lipids, which are separated by decantation after the addition of water [49]. This process provided greater efficiency in the reaction.

Yields and conversion rates into esters, obtained by methylic route, had the best results, which were expected, considering that methanol has a higher nucleophilicity than ethanol. As the degumming with phosphoric acid presented the best performance, the analysis thermogravimetric and determination of physicochemical parameters were carried out only for biodiesels prepared from $J$. curcas oil which had undergone such a process.

\subsubsection{Thermogravimetry}

The biodiesel is a mixture of alkyl esters, so its physical properties are very similar to pure esters. Therefore, it tends to show volatility and a boiling point that depend on the fatty acid composition, especially chain length and number of double bonds. Thus, for a specific biodiesel, the boiling point will be the average of fatty acid esters mixture [39-42].

Thermogravimetric analysis has been recommended as a rapid technique to measure the boiling point and vapor pressure of many organic compounds, including vegetable oils or alkyl esters. This method does not indicate visible evidence that the samples of esters decompose before or during the volatilization [39].

TG/DTG curves of MBJC and EBJC, which were prepared with $\mathrm{H}_{3} \mathrm{PO}_{4}$ degummed oil, showed similar results; in both, two thermal events were observed as shown in Table 5.

The first interval of mass loss observed for both biodiesels was in the range of $79.40-246.65{ }^{\circ} \mathrm{C}\left(79.47 \%\right.$; MBJC) and $77.88-263.30{ }^{\circ} \mathrm{C}$ $(80.10 \%$; EBJC); this is attributed to volatilization of unsaturated esters and lower molecular weight. The second thermal event was in the range of $246.65-301.14{ }^{\circ} \mathrm{C}(18.32 \%$; MBJC) and 263.30-338.22 ${ }^{\circ} \mathrm{C}(18.75 \%$; EBJC), and may be due to the higher molecular weight esters. The presence of esters in the samples is evidenced by the displacement of the main event, observed on the oil curve by lower temperatures, since these substances have boiling points lower than those of triacylglycerols, volatilizing therefore, in different temperatures [7]. TG/DTG curve did not show any events in the range of $304-505{ }^{\circ} \mathrm{C}$, suggesting that the transesterification reaction was complete [7]. The ethyl esters showed higher boiling points $\left(T_{\text {onset }}\right)$ than the methyl esters in the two thermal events and indeed were consistent with a view that the former has higher molecular weights (Table 5). The mass loss of the two thermal events showed positive correlation between the percentages of fatty acids unsaturated $(78.2 \%)$ and saturated $(21.8 \%)$ as determined by gas chromatography [50].

\subsubsection{Physicochemical parameters of $M B J C$ and EBJC}

The physicochemical parameters of MBJC and EBJC stood within the limits established by ANP Resolution 14/2012 (Table 6). The flash point of both samples, although within specifications, was less 
Table 6

Physical-chemical property of J. curcas methyl (MBJC) and ethyl (EBJC) biodiesel.

\begin{tabular}{|c|c|c|c|c|c|}
\hline Parameter & Unity & Method & $\mathrm{MBJC}$ & EBJC & ANP limits [38] \\
\hline Aspect & - & - & LII & LII & LII \\
\hline Density at $20^{\circ} \mathrm{C}$ & $\mathrm{kg} / \mathrm{m}^{3}$ & ASTM D 4052 & 875.9 & 874.0 & $850-900$ \\
\hline Viscosity at $40{ }^{\circ} \mathrm{C}$ & $\mathrm{mm}^{2} / \mathrm{s}$ & ASTM D 445 & 4.5400 & 4.9130 & $3.0-6.0$ \\
\hline Flash point, min. & ${ }^{\circ} \mathrm{C}$ & ASTM D 93 & 108.0 & 110.0 & 100.0 \\
\hline Carbon residue, max. & wt\% & ASTM D 189 & 0.0225 & 0.0309 & 0.10 \\
\hline Copper strip corrosion $\left(50^{\circ} \mathrm{C}, 3 \mathrm{~h}\right)$ & - & ASTM D 130 & $1 \mathrm{~b}$ & $1 \mathrm{~b}$ & 1 \\
\hline Cold filter plugging point, max. & ${ }^{\circ} \mathrm{C}$ & ASTM D 6371 & -1.0 & -2.0 & - \\
\hline Acid index, max. & $\mathrm{mg} \mathrm{KOH} / \mathrm{g}$ & IAL & 0.278 & 0.287 & 0.80 \\
\hline Free glycerin, max. & $w t \%$ & ASTM D 6584 & 0.0030 & 0.0027 & 0.02 \\
\hline Total glycerin, max. & wt\% & ASTM D 6584 & 0.0985 & 0.1752 & 0.38 \\
\hline Monoacylglycerol & wt\% & ASTM D 6584 & 0.0495 & 0.1624 & 0.80 \\
\hline Diacylglycerol & wt\% & ASTM D 6584 & 0,0158 & 0.0101 & 0.20 \\
\hline Triacylglycerol & wt\% & ASTM D 6584 & 0.0302 & 0.0000 & 0.20 \\
\hline Methanol, max. & wt $\%$ & EN 41110 & 0.0100 & 0.01 & 0.20 \\
\hline Oxidation stability at $110^{\circ} \mathrm{C}$ & $\mathrm{h}$ & EN 14112 & 13.51 & 13.03 & 6 \\
\hline
\end{tabular}

LII: limpid and exempt of impurities. IAL: Instituto Adolfo Lutz. ANP: National Agency of Petroleum, Natural Gas and Biofuels from Brazil.

than that reported in the literature for biodiesel methyl $\left(163-191{ }^{\circ} \mathrm{C}\right)$ and ethyl $\left(190{ }^{\circ} \mathrm{C}\right)[11,19]$. The residues of free and total glycerin were quite satisfactory and lower than those obtained by titrimetric analysis, which were $0.0192 \pm 0.0035 \%$ and $0.1779 \pm 0.0109 \%(\mathrm{MBJC})$, and $0.0203 \pm 0.0095 \%$ and $0.2268 \pm 0.0559 \%(\mathrm{EBJC})$ respectively.

Gas chromatography analyses showed quantities of mono, diand triacylglycerols in MBJC; however, the EBJC did not present triacylglycerols. Methanol is more reactive than ethanol, so we used $1 \mathrm{~h}$ to make the methyl route and $2 \mathrm{~h}$ for the ethyl route. However, the results showed the presence of triacylglycerol in biodiesel methyl only it is believed that the time of $1 \mathrm{~h}$ was not enough for total transesterification.

\subsubsection{Oxidation stability}

The oxidation stability of the biodiesels was relatively high $(\mathrm{MBJC}=13.51 \mathrm{~h}, \mathrm{EBJC}=13.03 \mathrm{~h})$. Values over $6 \mathrm{~h}$ were obtained without the addition of antioxidants. This corroborates the results of the lipid composition of the oil, which was mainly oleic acid, because it has only one double bond in the chain and the ester corresponding undergoes oxidation at a slower speed than the polyunsaturated esters. However, the conditions of storage, handling of raw materials and processing of biodiesel may compromise the oxidation stability [49]. Furthermore, depending on the treatment of the raw material, natural antioxidants such as tocopherols, carotenes, vitamin $\mathrm{C}$ and other phytochemicals, may be removed decreasing the stability. In research conducted by Sarin et al. [22] for example, biodiesel produced from J. curcas oil showed an induction period of 3:23 h, although the main constituent of the oil is also oleic acid. The results suggest that the oil J. curcas grown in Brazil is rich in natural antioxidants and these substances have not been fully removed in the degumming process used; industrially, this point is very important because it is not necessary to add antioxidants to this particular biodiesel.

\section{Conclusions}

The samples of Jatropha curcas L. (Physic nut) from TeresinaPiauí, Crateús-Ceará and Janaúba-Minas Gerais showed high levels of oil with $60.69,54.71$ and $64.16 \%$, respectively. Oleic acid was a major constituent, with a percentage of $42.30,41.77$ and $42.64 \%$. Degummed oils only, without any further processing or refining, showed conversion into esters very high; these results point to $\mathrm{H}_{3} \mathrm{PO}_{4}$ degumming as a more effective process than water degumming. The routes obtaining methyl and ethyl biodiesels showed physicochemical characteristics compatible with the limits established by ANP Resolution 05/2012. The TG/DTG curves showed the occurrence of transesterification reactions by the displacement of the main event as observed on the curve of oil and in the lowering of temperatures in view of the boiling points of the esters being lower than those of triacylglycerol. Analysis by ${ }^{1} \mathrm{H}$ NMR also confirmed the occurrence of the transesterification reaction of triacylglycerols in the oil and allowed determination of the rate of conversion into esters. The results about oxidation stability were good, because the biodiesels MBJC and EBJC have induction period of $13.51 \mathrm{~h}$ and $13.03 \mathrm{~h}$ without antioxidant addition when submitted a Rancimat text.

The results showed that $J$. curcas cultivation in Brazil represents an adequate source for biodiesel production, considering the technical standards available.

\section{Acknowledgments}

The authors would like to thank the Laboratório da Brasil Ecodiesel Associado à Pesquisa e Desenvolvimento/Eusébio-Ceará the NuBBE/UNESP/Araraquara-SP, LAPETRO-UFPI for some analysis. We are also thankful to CNPq (472012/2008-8), Coordenação de Aperfeiçoamento de Pessoal de Nível Superior, Brazil and FINEP (01.05.0441-00) for their financial support and scholarship.

\section{References}

[1] Taufiq-Yap YH, Lee HV, Hussein MZ, Yunus R. Calcium-based mixed oxide catalysts for methanolysis of Jatropha curcas oil to biodiesel. Biomass Bioenergy 2011;35:827-34.

[2] Sudhakar JT, Eswaran N, Sujatha M. Molecular approaches to improvement of Jatropha curcas Linn. as a sustainable energy crop. Plant Cell Rep 2011;30: 1573-91.

[3] Bozbas K. Biodiesel as an alternative motor fuel: production and policies in the European Union. Renew Sustain Energ Rev 2006;12:542-52.

[4] Soo-Young N. Inedible vegetable oils and their derivatives for alternative diesel fuels in CI engines: a review, renew, sustain. Energ Rev 2011;15: $131-49$.

[5] Haldar SK, Ghosh BB, Nag A. Studies on the comparison of performance and emission characteristics of a diesel engine using three degummed non-edible vegetable oils. Biomass Bioenergy 2009;33:1013-8.

[6] Endalew AK, Kiros Y, Zanzi R. Heterogeneous catalysis for biodiesel production from Jatropha curcas oil (JCO). Energy 2011;36:2693-700.

[7] Rashid U, Anwar F, Jamil A, Bhatti HN. Jatropha curcas seed oil as a viable source for biodiesel. Pak J Bot 2010;42:575-82.

[8] Makkar H, Maes J, De Greyt W, Becker K. Removal and degradation of phorbol esters during pre-treatment and transesterification of Jatropha curcas oil. J Am Oil Chem Soc 2009;86:173-81.

[9] Maiti S, Bapat P, Das P, Ghosh PK. Feasibility study of jatropha shell gasification for captive power generation in biodiesel production process from whole dry fruits. Fuel 2014;121:126-32. 
[10] Gofferjé G, Gebhardt M, Stabler A, Schweiggert-Weiz U, Floter E. Screening of impact factors on the enzymatic neutralization of jatropha crude oil. Eur J Lipid. Sci Technol 2014;116:185-92.

[11] Pecina-Quintero V, Anaya-López JL, Zamarripa-Colmenero A, Núñez-Colín CA Montes-García N, Solís-Bonilla JL, et al. Genetic structure of Jatropha curcas L. in Mexico and probable centre of origin. Biomass Bioenergy 2014;60:147-55.

[12] Openshaw K. A review of Jatropha curcas: an oil plant of unfulfilled promise. Biomass Bioenergy 2000;19:1-15.

[13] Heller J. Physic nut. Jatropha curcas L.: promoting the conservation and use of underutilized and neglected crops. 1. Rome: International Plant Genetic Resources Institute; 1996.

[14] Foidl N, Foidl G, Sanchez M, Mittelbach M, Hackel S. Jatropha curcas L. as a source for the production of biofuel in Nicaragua. Bioresour Technol 1996;58: $72-82$.

[15] Sirisomboon P, Kitchaiya P, Pholpho T, Mahuttanyavanitch W. Physical and mechanical properties of Jatropha curcas L. fruits, nuts and kernels. Biosyst Eng 2007;97:201-7.

[16] Fukuda H, Kondo A, Nod H. Biodiesel fuel production by transesterification of oils. J Biosci Bioeng 2011;92:405-16.

[17] Su E, Du L, Gong X, Wang P. Lipase-catalyzed irreversible transesterification of Jatropha curcas L. seed oil to fatty acid esters: an optimization study. J Am Oil Chem Soc 2011;88:793-800.

[18] Arruda FP, Beltrão NEM, Andrade AP, Pereira WE, Severino LS. Cultivo do pinhão manso como alternativa para o semi-árido nordestino. Rev Bras O Fibros 2004;8:789-99.

[19] Akintayo ET. Characteristics and composition of Parkia biglobbossa and Jatropha curcas oils and cakes. Bioresour Technol 2004:92:307-10.

[20] Azam MM, Waris A, Nahar NM. Prospects and potential of fatty acid methy esters of some non-traditional seed oils for use as biodiesel in India. Biomass Bioenergy 2005;29:293-302.

[21] Kpoviessi DSS, Accrombessi GC, Kossouoh C, Soumanou MM, Moudachirou M. Propriétés physico-chimiques et composition de l'huile non conventionnelle de pourghère (Jatropha curcas) de différentes régions du Bénin. C R Chim 2004; 7:1007-12.

[22] Sarin R, Sharma M, Sinharay S, Malhotra RK. Jatropha-palm biodiesel blends: an optimum mix for Asia. Fuel 2007;86:1365-71.

[23] Augustus GDPS, Jayabalan M, Seiler GJ. Evaluation and bioinduction of energy components of Jatropha curcas. Biomass Bioenergy 2002;23:161-4.

[24] Kumar A, Sharma S. An of multipurpose oil seed crop for industrial uses (Jatropha curcas L): a review. Ind Crops Prod 2008;28:1-10.

[25] Berchmans HJ, Hirata S. Biodiesel production from crude Jatropha curcas L. seed oil with a high content of free fatty acid. Bioresour Technol 2008;99: $1716-21$.

[26] Achten WMJ, Verchot L, Franken YJ, Mathijs E, Singh VP, Aerts R, et al. Jatropha bio-diesel production in use. Biomass Bioenergy 2008;32:1063-84.

[27] Corro G, Bañuelos F, Vidal E, Cebada S. Measurements of surface acidty catalysts for free fatty acids esterification in Jatropha curcas oil for biodiesel production. Fuel 2014;115:625-8.

[28] Liao C-C, Chung T-W. Optimization of process conditions using response surface methodology for the microwave-assisted transesterification of jatropha oil with $\mathrm{KOH}$ impregnated $\mathrm{CaO}$ as catalyst. Chem Eng Res Des 2013;91: 2457-64.

[29] IUPAC. Standard methods for analysis of oils, fats and derivatives. 7th ed. Blackwell Scientific Publications; 1987 [IUPAC Method 2.301, Report of IUPAC].
[30] Chaves MH, Barbosa AS, Moita Neto JM, Aued-Pimentel S, Lago JHG. Caracterização química do óleo da amêndoa de Sterculia striata St. Hil. et Naud. Quim Nova 2004;27:404-8.

[31] Aued-Pimentel S, Lago JHG, Chaves MH, Kumagai EE. Evaluation of a methylation procedure to determine cyclopropenoids fatty acids from Sterculia striata St. Hil. Et Nauds seed oil. J Chromatogr A 2004;1054:235-9.

[32] Moretto E, Fett R. Tecnologia de óleos e gorduras vegetais na indústria de alimentos. São Paulo: Livraria Varela; 1998.

[33] Lima JRO, Silva RB, Silva CCM, Santos LSS, Santos Jr JR, Moura EM, et al. Biodiesel de babaçu (Orbignya sp.) obtido por via etanólica. Quim Nova 2007;30: 600-3.

[34] Kumar MS, Ramesh A, Nagalingam B. An experimental comparison of methods to use methanol and jatropha oil in a compression ignition engine. Biomass Bioenergy 2003;25:309-18.

[35] Vicente G, Martínez M, Aracil J. Optimisation of integrated biodiesel production. Part I. A study of the biodiesel purity and yield. Bioresour Technol 2006; $98: 1724-33$.

[36] Meher LC, Sagar DV, Naik SN. Technical aspects of biodiesel production by transesterification-a review. Renew Sustain Energ Rev 2006;10:248-68.

[37] Silva RB, Lima Neto AF, Santos LSS, Lima JRO, Chaves MH, Santos Jr JR, et al Catalysts of $\mathrm{Cu}(\mathrm{II})$ and $\mathrm{Co}(\mathrm{II})$ ions adsorbed in chitosan used in transesterification of soy bean and babassu oils - a new route for biodiesel syntheses. Bioresour Technol 2008;99:6793-8.

[38] Resolution ANP Number 14. Brazilian national agency for petroleum, natural gas and biofuels. Available at: http://www.anp.gov.br; July 2012 [accessed on 10.09.13].

[39] Goodrum JW, Goodrum JW. Volatility and boiling points of biodiesel from vegetable oils and tallow. Biomass Bioenergy 2002;22:205-11.

[40] Goodrum JW, Geller DP, Lee SA. Rapid measurement of boiling points and vapor pressure of binary mixtures of short-chain triglycerides by TGA method. Thermochim Acta 1998:311:71-9.

[41] Goodrum JW, Geller DP. Rapid thermogravimetric measurements of boiling points and vapor pressure of saturated medium- and long-chain triglycerides. Bioresour Technol 2002;84:75-80.

[42] Antoniassi R. Métodos de avaliação da estabilidade oxidativa de óleos e gorduras. B Ceppa 2001;19:353-80.

[43] Moser BR. Efficacy of gossypol as an antioxidant additive in biodiesel. Renew Energy 2012;40:65-70.

[44] Agarwal D, Agarwal AK. Performance and emissions characteristics of jatropha oil (preheated and blends) in a direct injection compression ignition engine. Appl Therm Eng 2007;27:2314-23.

[45] Geris R, Santos NAC, Amaral BA, Maia IS, Castro VD, Carvalho JRM. Biodiesel de soja - reação de transesterificação para aulas práticas de química orgânica. Quim Nova 2007;30:1369-73.

[46] Knothe G, Kenar JA. Determination of the fatty acid profile by ${ }^{1} \mathrm{H}-\mathrm{NMR}$ spectroscopy. Eur J Lipid Sci Technol 2004;106:88-96.

[47] Silverstein RM, Webster FX, Kiemle DJ. Identificação espectrométrica de compostos orgânicos. 7th ed. Rio de Janeiro: LTC: 2006.

[48] Rinaldi R, Garcia C, Marciniuk LL, Rossi AV, Schuchardt U. Síntese de biodiesel: uma proposta contextualizada de experimento para laboratório de química geral. Quim Nova 2007;30:1374-80.

[49] Araújo JMA. Química de alimentos: teoria e prática. 2nd ed. Viçosa: UFV; 1999.

[50] Araújo FDS, Moura CVR, Chaves MH. Biodiesel metílico de Dipteryx lacunifera: preparação, caracterização e efeito de antioxidantes na estabilidade à oxidação. Quim Nova 2010;33:1671-6. 